\title{
Optimization of measurement and analysis parameters of burnishing surfaces
}

\author{
Optymalizacja parametrów pomiaru i analizy powierzchni nagniatanych
}

\begin{abstract}
ANETA ŁĘTOCHA
TATIANA MILLER

JANUSZ KALISZ*
\end{abstract}

DOI: https://doi.org/10.17814/mechanik.2017.11.171

\begin{abstract}
Studies related to the optimization of roughness measurements for surface topography obtained by milling and subsequent burnishing of hardened aluminum alloys, are presented. The measurements were made using the TOPO 01 contact profilometer. The best measurement parameters were selected. Additional measurements were also made with selected configuration, geometric surface analysis, and profile roughness statistics.
\end{abstract}

KEYWORDS: contact roughness measurement, sampling interval, measurement area, surface texture analysis

Przedstawiono badania związane z optymalizacją pomiarów chropowatości dla topografii powierzchni uzyskanych poprzez frezowanie, a następnie nagniatanie utwardzonego stopu aluminium. Pomiary wykonano profilometrem stykowym TOPO 01. Wybrano najlepsze parametry pomiaru. Wykonano także dodatkowe pomiary z wybrana konfiguracja, analizę struktury geometrycznej powierzchni oraz sporządzono statystykę parametrów chropowatości profilu.

SŁOWA KLUCZOWE: stykowe pomiary chropowatości, odstęp próbkowania, obszar pomiaru, analiza struktury geometrycznej powierzchni

Way of machine elements and another products wear is the most often depended from properties of them top layer, especially of surface texture, material hardness and residual stresses status that left after machining. Appropriate properties of top layer can be formed inter alia during finishing burnishing, based on item local cold plastic deformation as a result of force and kinetic cooperation of smooth tool and machined surface. Burnishing, as a finishing machining of the surface, causes decreasing of height surface roughness parameters, strengthening of material top layer, and also obtaining advantageous compressive stresses status. This results in increasing of surface abrasion resistance, allows for transfer of greater surface pressures and increases of wear fatigue strength [1].

The burnishing effect is dependent on many factors, inter alia: hardness and type of machined material, burnishing force, shape and size of burnishing tool, burnishing strategy and stepover. Burnishing after milling is a complex process, and final effect depends on way of surface preparing to burnishing. Therefore sequential tooling consisting of formative milling and finishing burnishing should be taken as a entirety [2].

Roughness profile measurements using contact profiling method are very accurate. The method is based on movement of measurement probe, equipped in inductive

\footnotetext{
* Mgr inż. Aneta Łętocha (aneta.letocha@ios.krakow.pl), mgr inż. Ta tiana Miller (tatiana.miller@ios.krakow.pl), dr inż. Janusz Kalisz (janusz. kalisz@ios.krakow.pl) - Instytut Zaawansowanych Technologii Wytwarzania
}

transmitter, along measured surface with selected speed. Cone-shaped, small diamond tip of the probe, with radius about few micrometres $(<10 \mu \mathrm{m})$, is vertically leaned out depending on the surface texture. Tip movement is converted on the electric signal and transmitted to measurement software. Areal measurement in contact method is based on measuring profiles in axis perpendicular to measurement direction, with constant distance. Profiles are converted on measured area [3-5].

Size of measured area and sampling interval in both axis are very important measurement parameters and can significantly influence on research results, and also decide how many important information we can get during measurements

\section{Samples, measurement and analysis}

During research 2 samples of EN AW-AICu4MgSi(A) aluminum alloy in hardened state T451 were used. Sample were milled using a monolithic ball-end cutter (VHM) of a $8 \mathrm{~mm}$ diameter with the cutting speed of $v_{\mathrm{c}}=350 \mathrm{~m} / \mathrm{min}$, the feed per tooth of $f_{\mathrm{z}}=0.04 \mathrm{~mm}$, the pitch (stepover) of $f_{\mathrm{wf}}=0.53 \mathrm{~mm}$ and the axial depth of cut (the back engagement) $a_{p}=0.5 \mathrm{~mm}$. Milling operation (fig. 1) was performed with the constant stepover and the tilt angle $(\psi)$ of $7.5^{\circ}$ in the direction perpendicular to the $Y$ axis.

Both milling and burnishing operations were carried out, each in one pass on a 5-axis machining centre model DMC 75V Linear. Burnishing was performed using a spring-loaded burnishing tool (produced by The Institute of Advanced Manufacturing Technology) equipped with a $\mathrm{Si}_{3} \mathrm{~N}_{4}$ ceramic polished ball of a $8 \mathrm{~mm}$ diameter. Before burnishing the burnishing tool was displaced at $0.3 \mathrm{~mm}$ in relation to the specimen surface by appropriate spring deflection. The working feed of the table was the same at $f_{\mathrm{t}}=8000 \mathrm{~mm} / \mathrm{min}$ for all burnishing sample [3].

The values of the elastic load were equal to $F_{\mathrm{n}}=75 \mathrm{~N}$ whereas the feed rates in the direction perpendicular to milling lays were equal to $f_{\mathrm{wn}}=0.02 \mathrm{~mm}$ and $0.04 \mathrm{~mm}$.

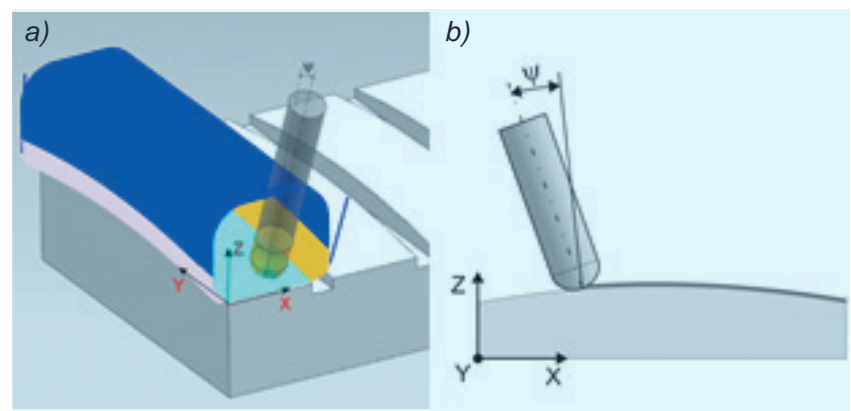

Fig. 1. Scheme of samples ball-end milling in the direction perpendicula to $Y$ axis $(a)$ and the tilt angle $(\psi)(b)$ 
During burnishing the ball was lubricated by machine oil. All CNC programs used are edited using a NX CAM programming system.

Surface texture measurements were performed using contact profilometer TOPO 01 constructed by The Institute of Advanced Manufacturing Technology (fig. 2). Instrument was equipped in probe with $2 \mu \mathrm{m}$ radius and $60^{\circ}$ angle cone tip. Measurement speed was $0.5 \mathrm{~mm} / \mathrm{s}$, sampling rate in $X$ axis (measurement direction axis) $\mathrm{d} X=0.5 \mu \mathrm{m}$. In order to find optimal measurement parameters performed tests with selected measurement distances in $Y$ axis (perpendicular to measurement direction): $2 \mathrm{~mm}, 1.5 \mathrm{~mm}, 1 \mathrm{~mm}, 0.5 \mathrm{~mm}$ and sampling intervals in $Y$ axis: $50 \mu \mathrm{m}, 20 \mu \mathrm{m}, 10 \mu \mathrm{m}, 5 \mu \mathrm{m}, 2 \mu \mathrm{m}, 1 \mu \mathrm{m}$. Results of height parameters of profile $(R a, R q, R p, R v, R z, R c, R t)$ and surface ( $S a, S q, S p, S v, S z)$ were analysed.

After selection of optimal measurement distance and sampling interval in axis perpendicular to measurement direction, additional tests with chosen parameters were performed.

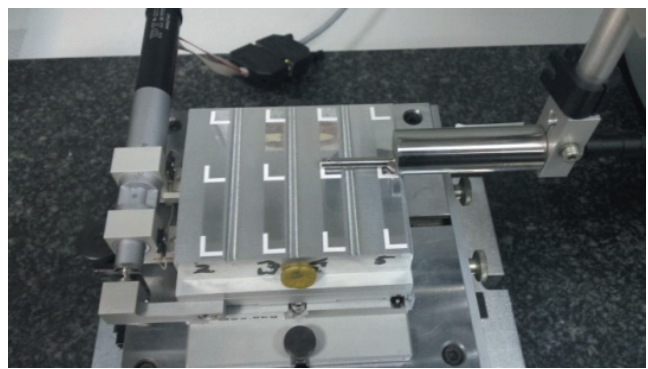

Fig. 2. Contact method measurement of burnished surfaces using TOPO 01 instrument

Results analysis was extended about another profile and surface roughness parameters: height parameters - Rsk, Rku, Ssk, Sku, distance parameter - RSm, material ratio parameters - Rmr(c), Smr(c), roughness core parameters: Rpk, Rk, Rvk, Mr1, Mr2, Spk, Sk, Svk, SMr1,

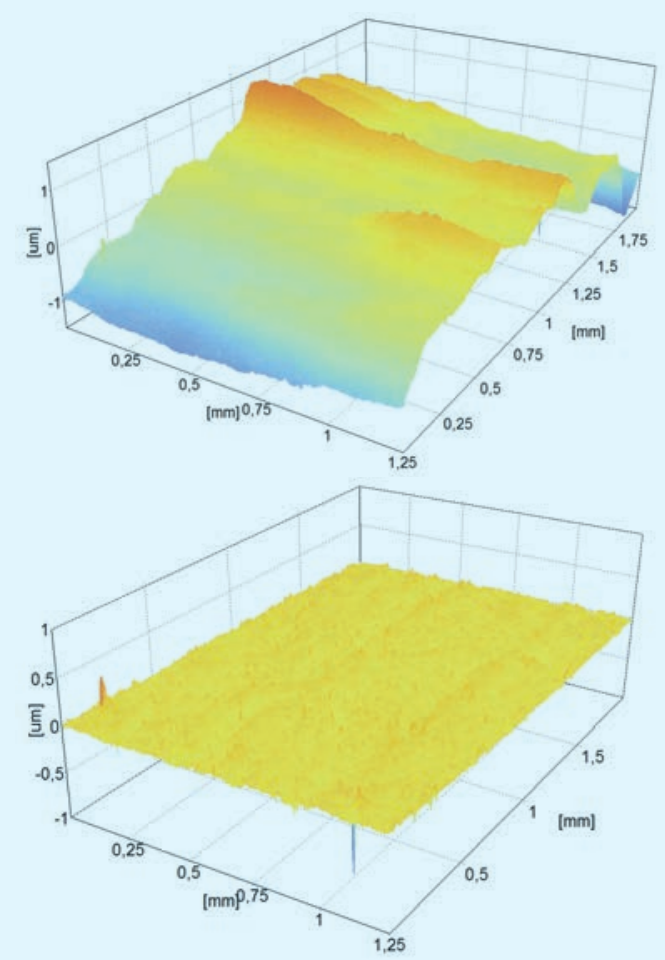

Fig. 3. Example of burnished sample measurement: a) primary surface, b) roughness surface
SMr2, and also volume parameters - Vmp, Vmc, $V v c, V v v$. Parameters best describing and giving some information about properties of burnished surfaces were selected.

\section{Results}

Roughness measurements of burnished surfaces are not a simple issue, inter alia because obtained surface accuracies are at the capabilities limit of measurement instruments. Additionally, for used material, burnished surfaces contain statistical deep valleys. The example of

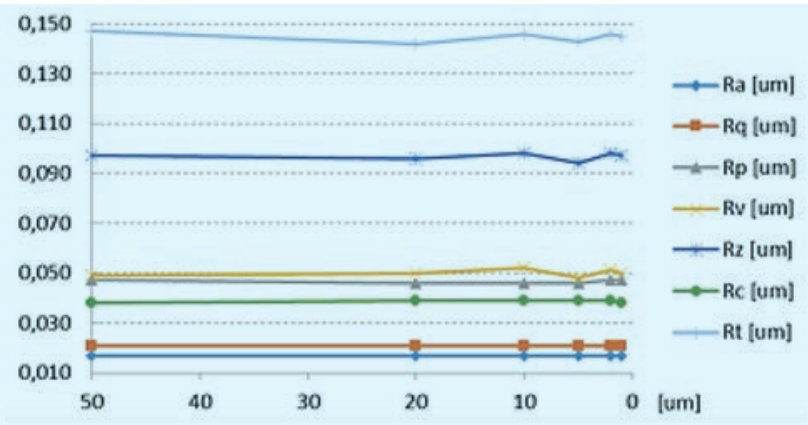

Fig. 4. Relationship between results of roughness parameters and sampling interval in $Y$ axis, for $0.5 \mathrm{~mm}$ measuring distance in $Y$ axis

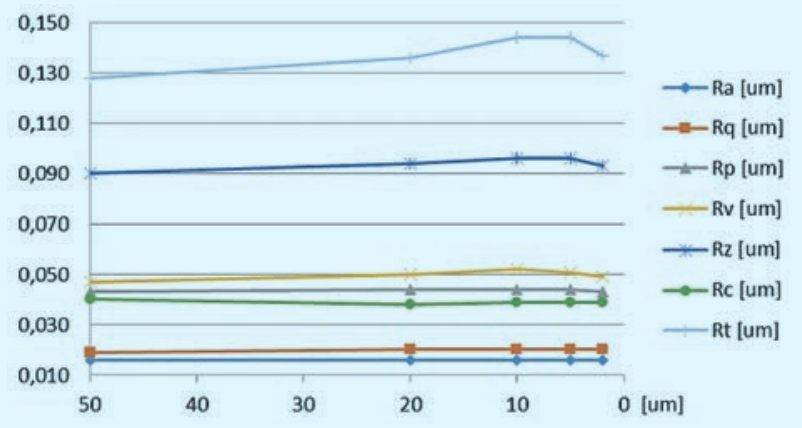

Fig. 5. Relationship between results of roughness parameters and sampling interval in $Y$ axis, for $1 \mathrm{~mm}$ measuring distance in $Y$ axis

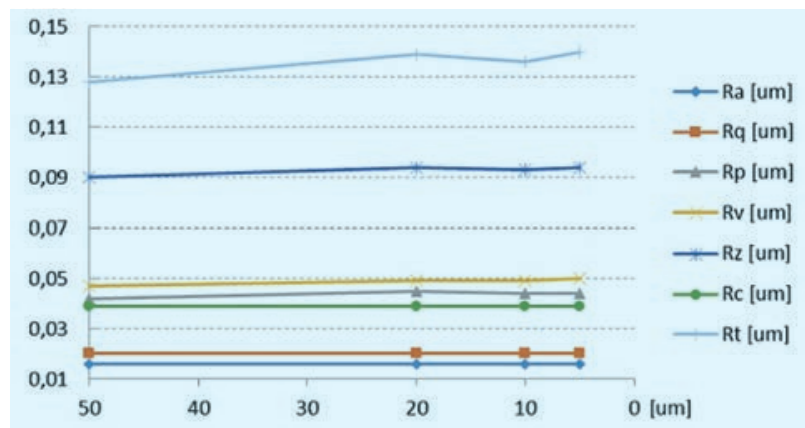

Fig. 6. Relationship between results of roughness parameters and sampling interval in $Y$ axis, for $1.5 \mathrm{~mm}$ measuring distance in $Y$ axis

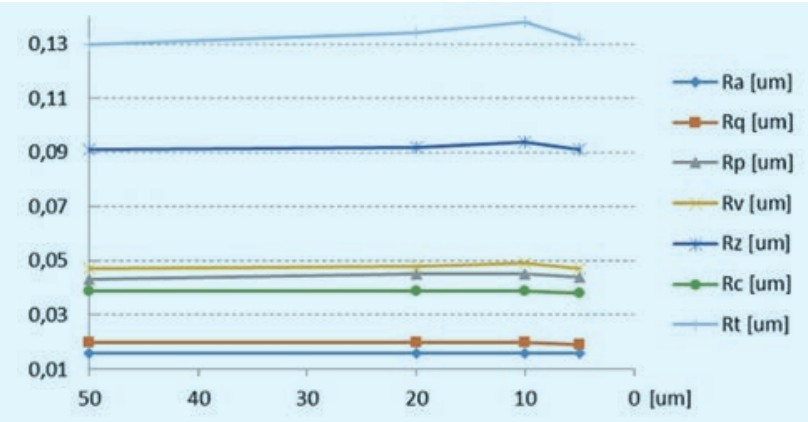

Fig. 7. Relationship between results of roughness parameters and sampling interval in $Y$ axis, for $2 \mathrm{~mm}$ measuring distance in $Y$ axis 


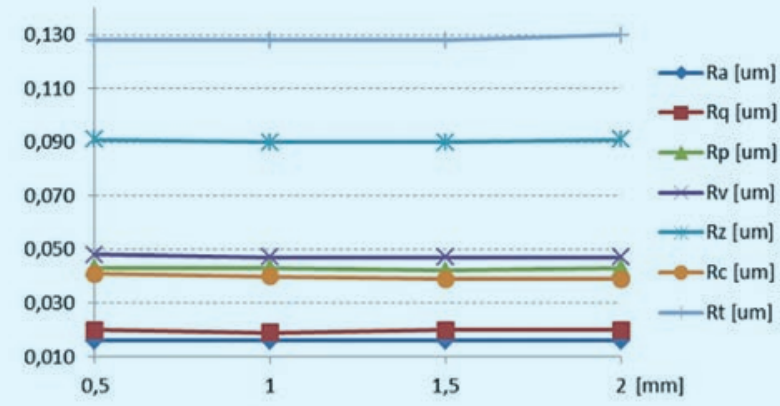

Fig. 8. Relationship between results of roughness parameters and measured distance in $Y$ axis, for $50 \mu \mathrm{m}$ sampling interval in $Y$ axis

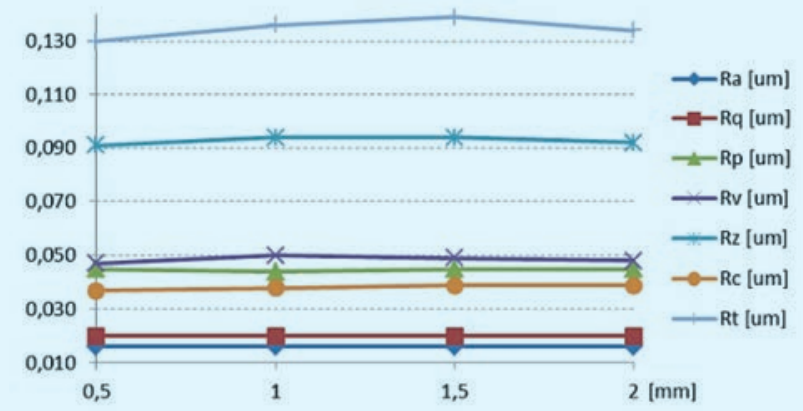

Fig. 9. Relationship between results of roughness parameters and measured distance in $Y$ axis, for $20 \mu \mathrm{m}$ sampling interval in $Y$ axis

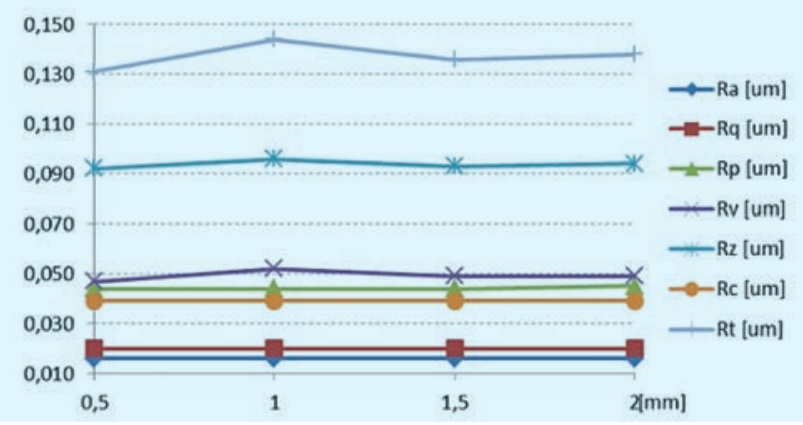

Fig. 10. Relationship between results of roughness parameters and measured distance in $Y$ axis, for $10 \mu \mathrm{m}$ sampling interval in $Y$ axis

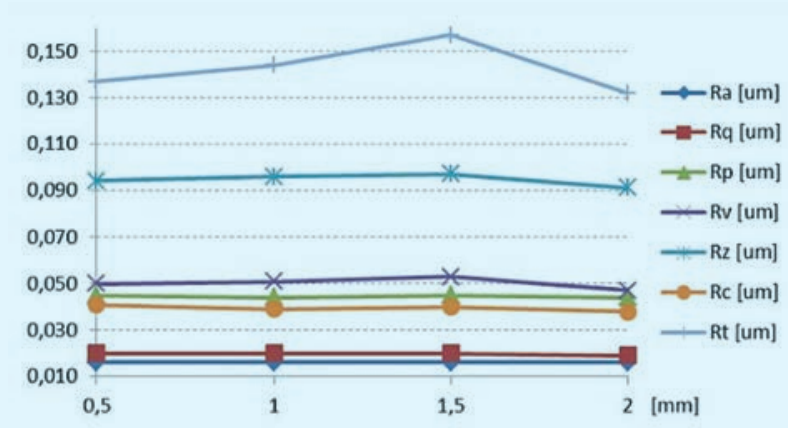

Fig. 11. Relationship between results of roughness parameters and measured distance in $Y$ axis, for $5 \mu \mathrm{m}$ sampling interval in $Y$ axis

measurement result of burnished surface is presented in fig. 3. Many measurements were performed. In paper results for sample number 30 are presented.

Graphs of the relationship between results of roughness parameters and sampling interval in $Y$ axis (perpendicular to measurement direction) for sample 30 are presented in: fig. $4-0.5 \mathrm{~mm}$ measuring distance in $Y$ axis, fig. $5-1$ $\mathrm{mm}$ measuring distance in $Y$ axis, fig. $6-1.5 \mathrm{~mm}$ measuring distance in $Y$ axis, fig. $7-2 \mathrm{~mm}$ measuring distance in $Y$ axis.

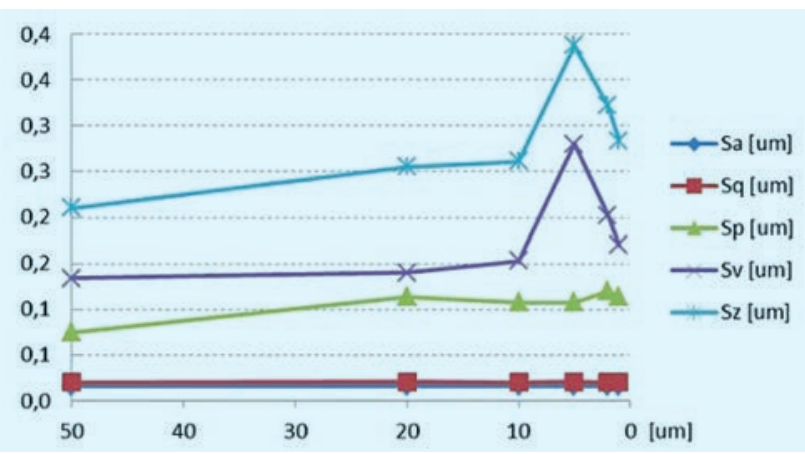

Fig. 12. Relationship between results of roughness surface parameters and sampling interval in $Y$ axis, for $0.5 \mathrm{~mm}$ measuring distance in $Y$ axis

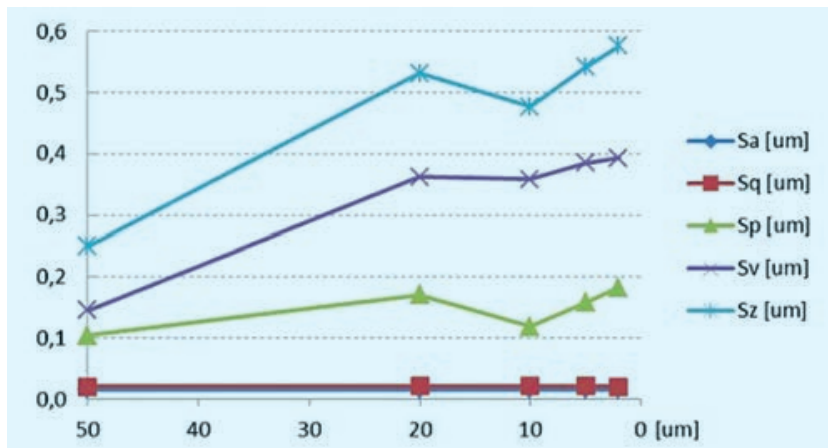

Fig. 13. Relationship between results of roughness surface parameters and sampling interval in $Y$ axis, for $1 \mathrm{~mm}$ measuring distance in $Y$ axis

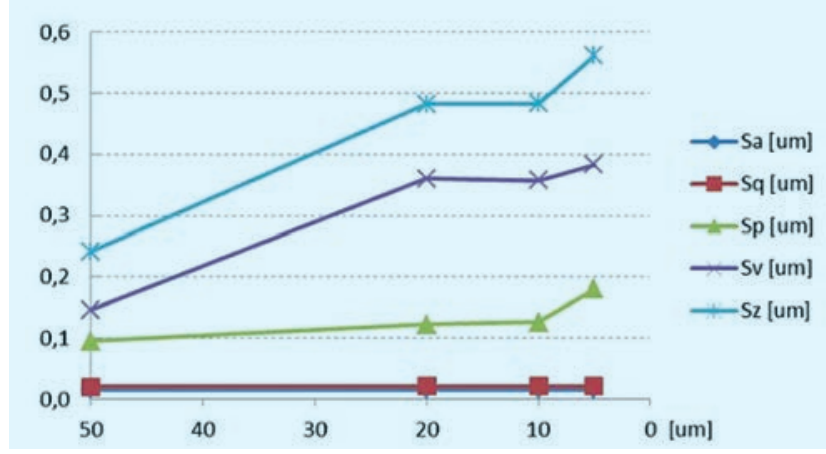

Fig. 14. Relationship between results of roughness surface parameters and sampling interval in $Y$ axis, for $1.5 \mathrm{~mm}$ measuring distance in $Y$ axis

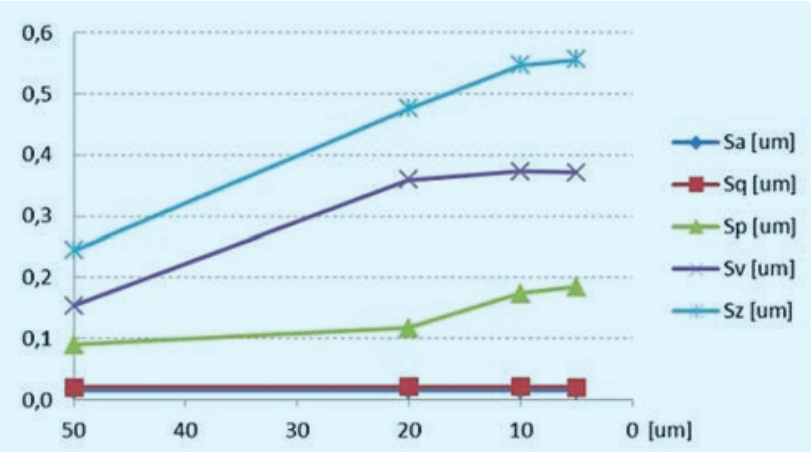

Fig. 15. Relationship between results of roughness surface parameters and sampling interval in $Y$ axis, for $2 \mathrm{~mm}$ measuring distance in $Y$ axis

Graphs of the relationship between results of roughness parameters and measurement distance in $Y$ axis (perpendicular to measurement direction) for sample 30 are presented in: fig. $8-50 \mu \mathrm{m}$ sampling interval in $Y$ axis, fig. $9-20 \mu \mathrm{m}$ measuring distance in $Y$ axis, fig. $10-10 \mu \mathrm{m}$ measuring distance in $Y$ axis, fig. $11-5 \mu$ m measuring distance in $Y$ axis. 
One can notice that while analysis in view of different measurement distances in $Y$ axis, the 2 smaller distances did not have significant changes in the results, and in view of different sampling intervals in $Y$ axis changes are the most visible for the smallest intervals. Parameters $R p, R v$, $R z, R t$ have greater deviations while measurement parameters changing. While averaged parameters as: $R a$, $R q, R c$, did not show changes regardless of the changes of sampling interval and measurement distance in $Y$ axis. It is visible that roughness parameters values change more with the change of the measurement distance in $Y$ axis, than with the change of the sampling interval in the same axis.

Surface texture analysis is presented in figs. 12-15. Graphs of the relationship between results of surface roughness parameters and sampling interval in $Y$ axis (perpendicular to measurement direction) are presented in: fig. $12-0.5 \mathrm{~mm}$ measuring distance in $Y$ axis, fig. 13 - $1 \mathrm{~mm}$ measuring distance in $Y$ axis, fig. $14-1.5 \mathrm{~mm}$ measuring distance in $Y$ axis, fig. $15-2 \mathrm{~mm}$ measuring distance in $Y$ axis.

Graphs of the relationship between results of roughness parameters and measurement distance in $Y$ axis (perpendicular to measurement direction) are presented in:

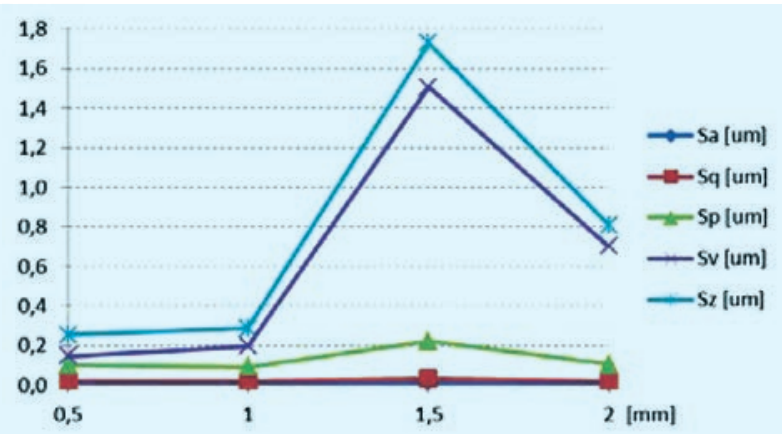

Fig. 16. Relationship between results of roughness parameters and measured distance in $Y$ axis, for $50 \mu \mathrm{m}$ sampling interval in $Y$ axis

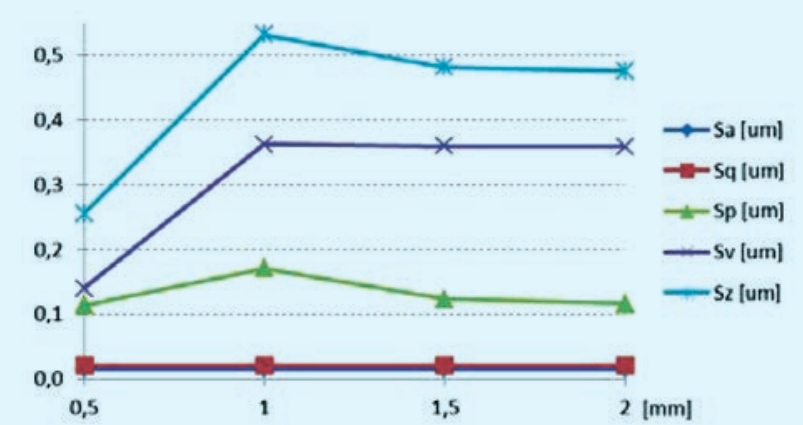

Fig. 17. Relationship between results of roughness parameters and measured distance in $Y$ axis, for $20 \mu \mathrm{m}$ sampling interval in $Y$ axis

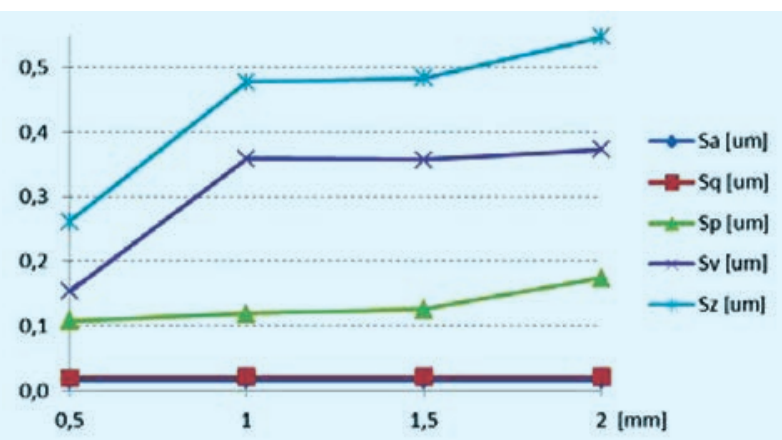

Fig. 18. Relationship between results of roughness parameters and measured distance in $Y$ axis, for $10 \mu \mathrm{m}$ sampling interval in $Y$ axis fig. $16-50 \mu \mathrm{m}$ sampling interval in $Y$ axis, fig. $17-20 \mu \mathrm{m}$ measuring distance in $Y$ axis, fig. $18-10 \mu \mathrm{m}$ measuring distance in $Y$ axis.

Similarly like for the statistical analysis of roughness profile, one can see that while analysis in view of different measurement distances in $Y$ axis, the longest distance the more visible changes in the results, and in view of different sampling intervals in $Y$ axis - the smallest sampling intervals - the most visible changes. Parameters Sp, Sv, $S z$ have greater deviations while changing of measurement parameters. While averaged parameters as Sa and $\mathrm{Sq}$ did not show changes regardless of the changes of sampling interval and measurement distance in $Y$ axis.

In order to find optimal measurement parameters for research of roughness profiles and surfaces of burnished samples, additional analysis was performed - tables I-IV. The analysis was based on calculation which measurement configuration gives the most often maximum, and also possibly close $(<1 \mathrm{~nm}$ than maximum values) to

TABLE I. Profile measurements. Numbers of maximum results of each sampling intervals in $Y$ axis

\begin{tabular}{|c|c|c|c|c|c|c|}
\hline \multirow{2}{*}{$\mathrm{d} Y, \mu \mathrm{m}$} & \multicolumn{4}{|c|}{ Distance in $Y$ axis, $\mathrm{mm}$} & \multirow[t]{2}{*}{ Total } & \multirow[t]{2}{*}{$F^{*}$} \\
\hline & 0.5 & 1.0 & 1.5 & 2.0 & & \\
\hline 50 & 4 & 1 & 4 & 2 & 11 & 2.75 \\
\hline 20 & 2 & 1 & 7 & 5 & 15 & 3.75 \\
\hline 10 & 5 & 1 & 5 & 8 & 19 & 4.75 \\
\hline 5 & 9 & 8 & 4 & 4 & 25 & 6.25 \\
\hline 2 & 9 & 1 & - & - & 10 & 5 \\
\hline 1 & 3 & - & - & - & 3 & 3 \\
\hline
\end{tabular}

* Number of maximum results divided by the number of performed measurements.

TABLE II. Profile measurements. Numbers of maximum results of each measurement distances in $Y$ axis

\begin{tabular}{|c|c|c|c|c|c|c|c|c|}
\hline \multirow{2}{*}{$\begin{array}{l}\text { Dist., } \\
\text { mm }\end{array}$} & \multicolumn{6}{|c|}{ Sampling rate in $Y$ axis, $\mu \mathrm{m}$} & \multirow{2}{*}{ Total } & \multirow{2}{*}{$F^{\star}$} \\
\hline & 50 & 20 & 10 & 5 & 2 & 1 & & \\
\hline 0.5 & 2 & 2 & 1 & 1 & 3 & 1 & 10 & 1.67 \\
\hline 1.0 & 5 & 5 & 4 & 7 & 0 & - & 21 & 4.20 \\
\hline 1.5 & 8 & 10 & 9 & 8 & - & - & 35 & 8.75 \\
\hline 2.0 & 6 & 7 & 4 & 4 & - & - & 21 & 5.25 \\
\hline
\end{tabular}

* Number of maximum results divided by the number of performed measurements.

TABLE III. Areal measurements. Numbers of maximum results of each sampling intervals in $Y$ axis $(d Y)$

\begin{tabular}{|c|c|c|c|c|c|c|}
\hline \multirow{2}{*}{$\mathrm{d} Y, \mu \mathrm{m}$} & \multicolumn{4}{|c|}{ Distance in $Y$ axis, $\mathrm{mm}$} & \multirow{2}{*}{ Total } & \multirow{2}{*}{$F^{\star}$} \\
\hline & 0.5 & 1.0 & 1.5 & 2.0 & & \\
\hline 50 & 0 & 0 & 1 & 0 & 1 & 0.25 \\
\hline 20 & 0 & 0 & 2 & 1 & 3 & 0.75 \\
\hline 10 & 0 & 0 & 1 & 5 & 6 & 1.5 \\
\hline 5 & 2 & 2 & 6 & 6 & 16 & 4.0 \\
\hline 2 & 3 & 6 & - & - & 9 & 4.5 \\
\hline 1 & 4 & - & - & - & 4 & 4.0 \\
\hline
\end{tabular}

* Number of maximum results divided by the number of performed measurements.

TABLE IV. Areal measurements. Numbers of maximum results of each measurement distances in $Y$ axis

\begin{tabular}{|c|c|c|c|c|c|c|c|c|}
\hline \multirow{2}{*}{$\begin{array}{c}\text { Dist., } \\
\mathrm{mm}\end{array}$} & \multicolumn{6}{|c|}{ Sampling rate in $Y$ axis, $\mu \mathrm{m}$} & \multirow{2}{*}{ Total } & \multirow{2}{*}{$F^{*}$} \\
\hline & 50 & 20 & 10 & 5 & 2 & 1 & & \\
\hline 0.5 & 1 & 0 & 0 & 0 & 0 & 1 & 2 & 0.33 \\
\hline 1.0 & 2 & 6 & 2 & 3 & 3 & - & 16 & 3.2 \\
\hline 1.5 & 4 & 4 & 1 & 3 & - & - & 12 & 3.0 \\
\hline 2.0 & 3 & 3 & 8 & 6 & - & - & 20 & 5.0 \\
\hline
\end{tabular}

* Number of maximum results divided by the number of performed measurements. 
maximum, values of roughness parameters. Parameters with results range less than $1 \mathrm{~nm}$ was not taken into consideration. In case of $1 \mu \mathrm{m}$ sampling interval hardware capabilities allows on performing 1 measurement only (only $1.25 \times 0.5 \mathrm{~mm}$ area), and for $2 \mu \mathrm{m}$ sampling interval - only 2 , therefore for optimal sampling interval in $Y$ axis selection, number of maximum results was divided by the number of performed measurements. The highest result was accepted as optimal. The same steps were applied while selection of optimal measurement distance in axis perpendicular to measurement direction.

For measurements performed in order to statistical analysis of the roughness profiles optimal distance in axis perpendicular to measurement direction is equal $1.5 \mathrm{~mm}$, and sampling interval in this axis is equal $5 \mu \mathrm{m}$. For measurements performed in order to roughness texture analysis optimal distance in axis perpendicular to measurement direction is equal $2 \mathrm{~mm}$. In case of optimal sampling interval of $Y$ axis in surface texture measurements, the most accurate results were obtained for $2 \mu \mathrm{m}$ sampling interval, but his value was not selected, because it would

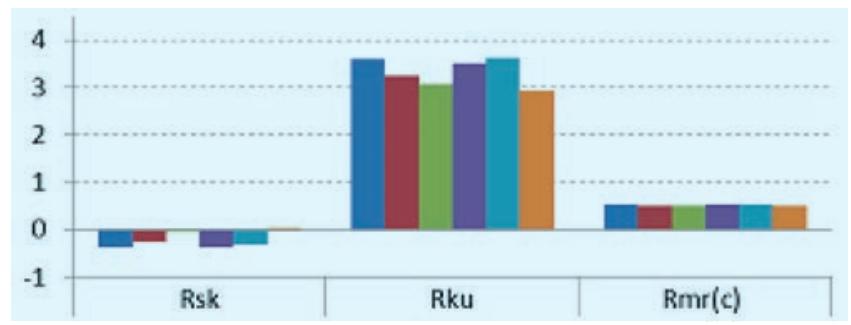

Fig. 19. Mean values of roughness profile parameters: $R s k, R k u, R m r(c)$ (for 0 level), of 6 measurement areas on 30 sample

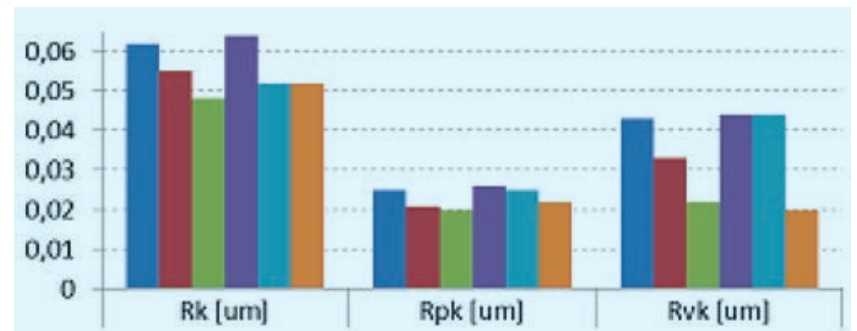

Fig. 20. Mean values of roughness profile parameters: $R k, R p k, R v k$, of 6 measurement areas on 30 sample

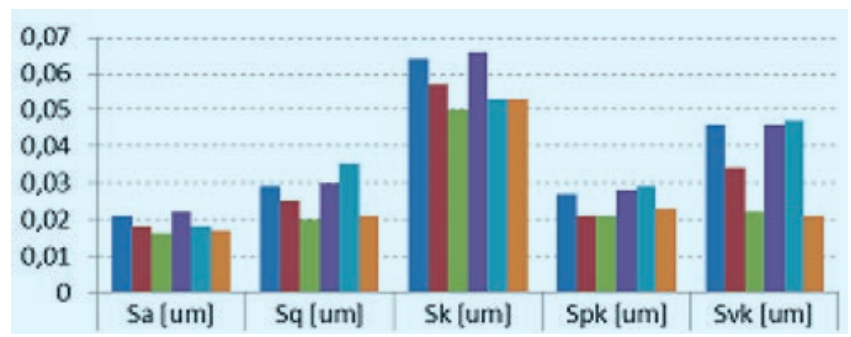

Fig. 21. Values of roughness surface parameters: Sa, Sq, Sk, Spk, Svk of 6 measurement areas on 30 sample

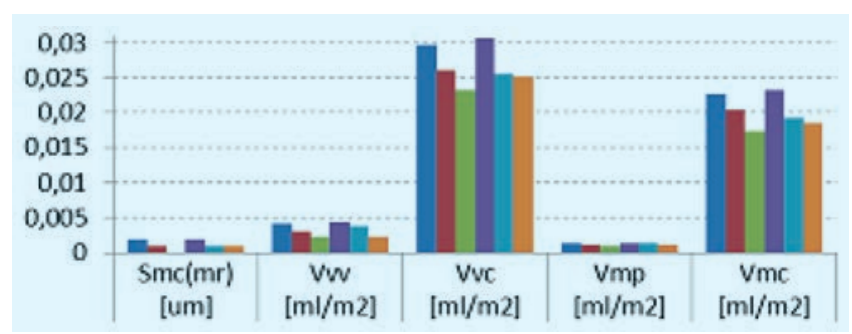

Fig. 22. Values of roughness surface parameters: $\operatorname{Smc}(m r)$ (for $50 \%$ ), $V v v, V v c, V m p, V m c$ of 6 measurement areas on 30 sample reduce measurement area to $1.25 \times 1 \mathrm{~mm}$ (hardware capabilities). Taking into account all of the results one can see, that changes of measurement distance in axis perpendicular to measurement direction $(Y)$ causes greater differences in results, than changes of sampling interval in $Y$ axis. Therefore, to be able to perform measurements on $1.25 \times 2 \mathrm{~mm}$ area, as optimal sampling interval was selected $5 \mu \mathrm{m}$.

In fig. 19 and 20 presented are examples of extended roughness profiles analysis results of additional measurements performed with optimal measurement parameters in different places on burnished sample.

In fig. 21 and 22 presented are examples of extended surface texture analysis results of additional measurements performed with optimal measurement parameters in different places on burnished sample.

While burnished surfaces measurements one of the important thing is to specify character of existing valleys how deep they are (helpful can be Rv, Sv, Spk, Sk, Svk parameters), how many they are (helpful can be $R k u$ and Sku parameters), and how big they are (helpful can be $V v c$ and $V v v$ parameters). Due to statistic deep valleys it is advantageously to determine if given measured burnished surface is symmetrical. We can do it after calculating Spk and Svk, and also Rmr(c), Smr(c), Smc(mr) parameters.

\section{Conclusions}

In statistical analysis of the roughness profiles optimal measurement parameters are as follows: distance in axis perpendicular to measurement direction $-1.5 \mathrm{~mm}$, sampling interval in this axis: $5 \mu \mathrm{m}$. In surface roughness analysis optimal measurement parameters are: distance in axis perpendicular to measurement direction $-2 \mathrm{~mm}$, sampling interval in this axis: $5 \mu \mathrm{m}$.

Greater differences are visible while comparing results of different measurement areas than for different sampling intervals in axis perpendicular to measurement direction.

Averaged roughness parameters $(R a, R q, R c, S a, S q)$ do not show differences regardless of selected measurement parameters.

The most useful roughness parameters used for properties evaluation of burnished surfaces are: height parameters, especially - Rv, Sv, Rku and Sku, roughness core parameters - Spk, Sk, Svk and volume parameters $V v c$ and $V v v$.

It is important to determine if surface or profile are symmetrical. It can be done with use of parameters: Spk and Svk, and also $\operatorname{Rmr}(c), \operatorname{Smr}(c), \operatorname{Smc}(m r)$.

The study constitutes a part of the project no. PBS2/ A6/20/2013/NCBiR/24/10/2013 "Research and evaluation of reliability of modern methods of surface topography measurements in micro and nano scale".

\section{REFERENCES}

1. Przybylski W. „Technologia obróbki nagniataniem”. Warszawa: Wydawnictwo Naukowo-Techniczne, 1987

2. Grochała D., Chmielewski K., Olszak W. "Badania wpływu technologicznych parametrów frezowania i nagniatania na topografię powierzchni". XII Konferencja Naukowa Technologia obróbki przez nagniatanie. Mechanik (CD). 11 (2014): pp. 90-99.

3. Jakubiec W., Zator S., Majda P. „Metrologia”. Warszawa: Polskie Wydawnictwo Ekonomiczne, 2014.

4. Wieczorowski M. "Metrologia nierówności powierzchni. Metody i systemy". Szczecin: ZAPOL, 2013.

5. Wieczorowski M. „Wykorzystanie analizy topograficznej w pomiarach nierówności powierzchni”. Poznań: Wydawnictwo Politechniki Poznańskiej, 2009. 